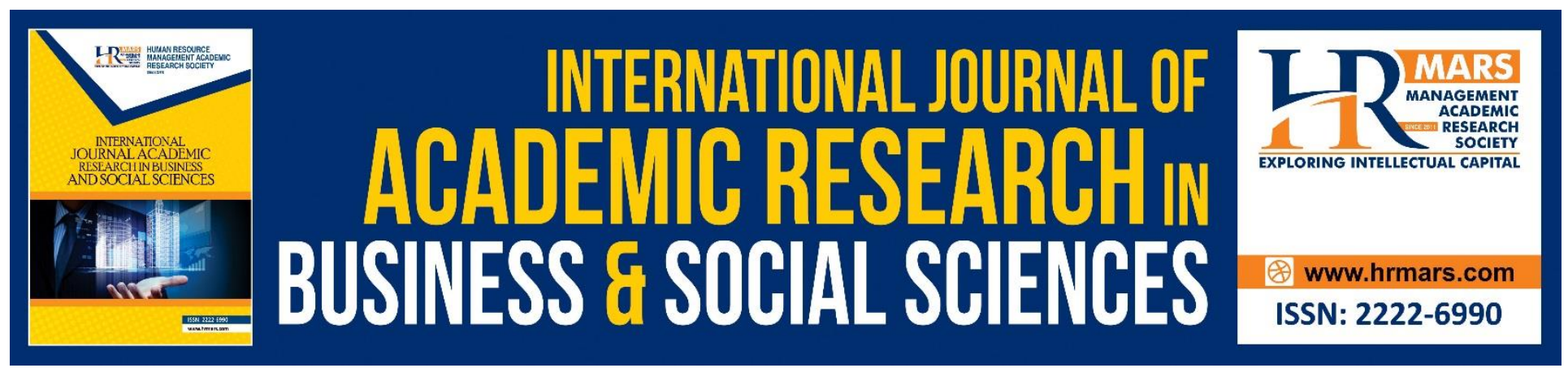

\title{
Introducing Environmental Awareness to College Students with Curricular and Extracurricular Activities
}

\author{
Yunus Yildiz \\ Taylan Budur
}

To Link this Article: http://dx.doi.org/10.6007/IJARBSS/v9-i3/5734

DOI: $\quad 10.6007 /$ IJARBSS/v9-i3/5734

Received: 12 Feb 2019, Revised: 09 March 2019, Accepted: 23 March 2019

Published Online: 02 April 2019

In-Text Citation: (Yildiz \& Budur, 2019)

To Cite this Article: Yildiz, Y., \& Budur, T. (2019). Introducing Environmental Awareness to College Students with Curricular and Extracurricular Activities. International Journal of Academic Research in Business and Social Sciences, 9(3), 666-675.

\section{Copyright: (C) 2019 The Author(s)}

Published by Human Resource Management Academic Research Society (www.hrmars.com)

This article is published under the Creative Commons Attribution (CC BY 4.0) license. Anyone may reproduce, distribute, translate and create derivative works of this article (for both commercial and non-commercial purposes), subject to full attribution to the original publication and authors. The full terms of this license may be seen

at: $\underline{\text { http://creativecommons.org/licences/by/4.0/legalcode }}$

Vol. 9, No. 3, 2019, Pg. 666 - 675

http://hrmars.com/index.php/pages/detail/IJARBSS

JOURNAL HOMEPAGE

Full Terms \& Conditions of access and use can be found at http://hrmars.com/index.php/pages/detail/publication-ethics 


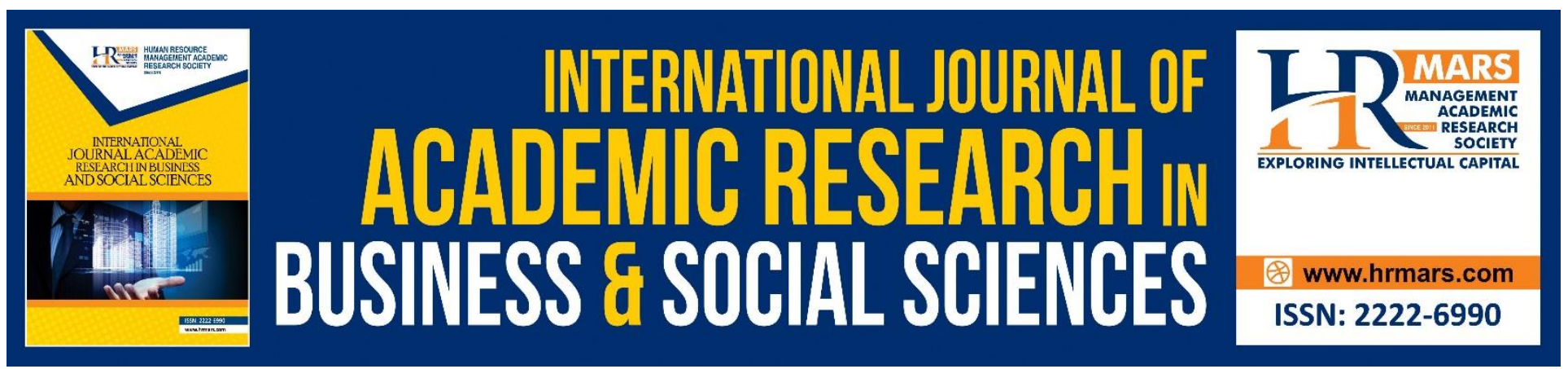

\title{
Introducing Environmental Awareness to College Students with Curricular and Extracurricular Activities
}

\author{
Yunus Yildiz \\ Department of Languages, Faculty of Education, Tishk International University, Erbil/IRAQ \\ Email: yunus.yildiz@ishik.edu.iq
}

Taylan Budur

Department of Business and Management, Faculty of Business Administration, Tishk International University, Sulaymaniyah/IRAQ

Email: taylan.budur@ishik.edu.iq

\begin{abstract}
The aim of this article is to transfer the vital importance of environmental awareness by emphasizing the value of curricular and extracurricular activities to college students.

In this study, the researchers observed his 30 learners' environmental awareness in his class by pre and post-survey statements. The study lasted only for 12 weeks. After the eight weeks of class management, the researchers had a picnic and poster competition among his learners and has commented the change of students' awareness in pre and post survey figures.

The researchers' observation and pre-survey indicate that students are not completely aware about why they need to keep the environment clean showing their lack of interest in environmental issues in actions. Because of this, educational institutions should undertake various within and out of school activities to enhance students' awareness in the field of tree planting, monthly clean-ups, re-using and re-cycling products seminars. Herewith, the researchers remind that the more the school or teacher uses class or school activities regarding the environment, the more positive attitudes the student has toward it as people learn by doing in person and peer pressure. Therefore, educators at any institutions should arrange activities with students together either in school or in nature.
\end{abstract}

Keywords: Curricular Activities, Extracurricular Activities, Nature, Environmental Awareness.

\section{Introduction}

Clearly, individuals in all parts of the world have been facing with different natural issues (for example air, water, floods, and soil contamination), not only locally, but also in a worldwide scale (for example a dangerous atmospheric deviation, global warming, melting glaciers, poisoned oceans) since the start of the twentieth century and particularly in this century, there are amazing increments in the 
measure of local and worldwide ecological issues. These continuing changes around forced the governments to take precautions and reminded concerned people the importance of environmental education (Ünal ve Dımışkı, 1999). The explanations for the rise of these issues are for the most part identified with financial development, industrialization, the global population explosion, growing demand for food, the limits in increasing supply, deforestation, and the extinction of biological resources (Palmer, 1998; Smati, 2004).

Until ongoing days, individuals didn't know about their job in the rise of these issues and their negative effect on the common habitat. In spite of individuals' having understood the effects of these natural issues on their life, they have still proceeded to drain ecological assets and have not changed the manner in which they live. There is a clear need to be aware of these problems and to quit the extensive use of environmental resources if we are in charge of protecting the environment and would like to have a sustainable future. Directly in this specific circumstance, training has a foremost job to make individuals mindful of the perfect condition and the personal satisfaction that is picked up by clean environment. Similarly, as a part of the solution, education in general and environmental education in particular mean a lot to educators and learners and as a matter of fact it is essential to use educational institutions to acquire and strengthen environmentally friendly young minds (Brynjegard, 2001).

An overview of accessible writing on natural mindfulness shows that the connection of ecological mindfulness with natural learning, mentalities and dependable conduct has been explored in a few investigations (for example: Kadji-Beltran, Barker and Raper, 2001; Korhonen and Lappalainen, 2004; Palmerg and Kuru, 2000). Many of these studies reveal that students' environmental awareness that could contribute to the development of their environmental knowledge, attitudes (Chawla and Cushing, 2007), sense of responsibility and their motivation to behave responsibly (Korhonen and Lappalainen, 2004) which are assumed to be gained products of environmental education (Hungerford and Volk, 1984).

There are a few sources which can help to create natural mindfulness. These sources can be for the most part ordered as media (printed and visual), family and the school. Field trips (O'Neal and Skelton, 1994), community inventory projects, community action projects as school activities (Howe and Disinger, 1988). Furthermore, as pointed out by Brynjegard (2001), school gardens are excellent places to introduce the concept of environmental awareness for students.

School gardens are the best places to educate and aware the learners to give them responsibility in the arranging, organizing and decorating the fields. Introducing environmental issues to students to integrate environmentally related subjects into traditional course offerings can be another solution (Wagner, 1997). In addition, outdoor activities such as field trips, having picnic in green areas, walking in the nature or trekking and hiking activities will help educators and students with opportunities to absorb environmental issues and these techniques are recognized as effective means of teaching awareness of the environment (Palmerg and Kuru, 2000; Howe and Disinger, 1988). Media, including television, radio, newspaper and magazines, also have a paramount role in developing the environmental awareness of students. Nowadays, social media like Facebook, Instagram, Pinterest 
INTERNATIONAL JOURNAL OF ACADEMIC RESEARCH IN BUSINESS AND SOCIAL SCIENCES

Vol. 9, No. 3, March, 2019, E-ISSN: 222 2-6990 ㄷ 2019 HRMARS

and Snapchats are good platforms to share the pictures, mottos or ideas to public. Similarly, the family has a strong influence on the children's awareness of environmental issues (Wagner, 1997). Building environmental awareness can be provided by the quality of environmental education and recent studies have been working on it (Erdoğan, 2011).

It is high time we mentioned what we can do with curricular and extracurricular activities to foster students' environmental education and awareness.

\section{Curricular and Extracurricular Activities}

Curricular activities are those offered in the formal curriculum to conduct and are a must, in the schedule and in the books. It comes from the authority or the government. Teachers say that because of the time limitations, they cannot do much in lessons except lecturing and question-and-answer sessions when teaching environmentally related topics. Therefore, we expect extra studies and awareness from the educators. Actually, the main issue might be solved having committed educators in schools. "Committed teachers are those who have excitement, passion, desire, enthusiasm and energy" to change the environment (Yildiz \& Celik, 2017).

On the other hand, as part of their instructions, they may find creative activities associated with recycling and re-using products (e.g. clothes, books, glass, etc.). Teachers can encourage their students to prepare PowerPoint and poster presentations by using the computer. Teachers can give research homework on environmental issues which allow students to be involved in both group and individual projects to develop basic skills as well as environmental awareness.

As curricular activities, students, for example, can be directed to attend science festivals, seminars, discussions and exhibitions. The students might be involved with cleaning up, recycling and planting. Experiments and problem solving activities regarding environmental problems are also great. In Japan, students are responsible to clean their classroom or cook their meals at school as a group activity.

As part of extra-curricular activities, the students can be encouraged to participate in international projects and conferences to share their knowledge with other audiences. Through the eco-school projects, the learners may attend field trips, observations and take part in bird watching activities.

Students' environmental awareness can enhance by means of several activities. Thus, if a student has environmental awareness, s/he tends to demonstrate various types of responsible behavior, such as keeping the environment clean, recycling and re-using products, saving water and energy, tree planting, warning others, and attending environmental projects in school. However, as in an English proverb 'Early bird catches the warm' age factor plays a great role in shaping responsible behavior. Students are more responsible at a younger age. Then, when the students grow older, their affective tendencies decrease and they tend to demonstrate irresponsible behavior. Nowadays, if we observe the learners, we definitely see the students who dirty their environment and are not very sensitive toward living organisms and plants ...

Thus, first environmental education should be given at the early ages of a child in the family. If not, educators should work on it in the institutions starting from the first grade. 


\section{Power of Extracurricular Activities on Environmental Awareness}

It is experienced that outdoor activities have a great impact on students 'gaining higher self confidence and feeling of safety when compared to those who had not experienced outdoor activities (Hattie, Marsh, Neill, and Richards, 1997).

The learners who are in outdoors can comprehend the significance of nature and express their nervousness about it. The students won't be just mindful of worldwide and neighborhood natural issues, however can feel concrete ecological issues. They will have profound worry about creatures, contamination and trees. The research will expand the mindfulness and learning of ecological move procedures to make activity.

Indoor and open air activities affect creating ecological frames of mind and a comprehension of natural issues. By means of environmental education program students' positive attitudes toward the environment foster. People get influenced positively or negatively from each other's actions as in a proverb indicated 'action speaks louder than words'. It is seen that there is no separate environmental education course in many educational systems that helps students become aware of the natural environment. Hence, there is a need to develop students' environmental awareness and sensitivity toward the environment through curricular and extracurricular activities, as well as by integrating environmentally-related topics into other course subjects. Establishing and carrying out any school activities or programs to develop such affective tendencies (awareness and sensitivity raising) is crucially important. Thus, this study might provide in-depth information about within and out-of school environmental activities for curriculum developers and teachers who plan to design such activities.

When we have environmentally aware individuals, students will protect their environment, produce solutions for environmental problems, warn other people who dirty the environment, and share their knowledge on the environment with their peers, friends and parents. Yet, 'school administration, teachers, students should be involved (Yildiz, 2016)' in those activities. These are all perceived as characteristics of students who are potentially environmental aware.

\section{Method}

This study is a quantitative research in which the researchers used two surveys and the first survey was taken in the second week of the study and the last survey was done in the ninth week of the study. The aim of the research was to increase the students' sense about environmental awareness issue in Kurdistan region of Iraq. The repliers of the survey statements were English language learners who were taking ten hours a week foundation English course from dentistry and interior design departments of a private university. Those thirty students were 24 girls and 6 boys and between the age of 18 and 21 .

\section{Results and Discussions}

\section{Students' Perceptions about Environmental Problems in the first Survey}

Pre-survey statements uncovers that learners' information and consciousness of nearby and worldwide ecological issues are to some degree constrained. Students can discuss a few ecological issues where they live, in Kurdistan overall, and on the planet, yet these issues are commonly known by numerous individuals in society. For example, leaving garbage on the road, throwing plastic bottles 
INTERNATIONAL JOURNAL OF ACADEMIC RESEARCH IN BUSINESS AND SOCIAL SCIENCES Vol. 9, No. 3, March, 2019, E-ISSN: 222 2-6990 (C) 2019 HRMARS

or fruit peels from the vehicle's window to the street, leaving the picnic territory grimy are some of them. The issues to care the most in Kurdistan are drinking water, soil and air contamination, and deficient waste.

Pre Survey - First Classification: What I understand from environmental awareness

8. I throw plastic water bottles or fruit peels from the...

7. I clean the picnic area after having a picnic.

6. I care closing the water tap if I see that running.

5. I re-use the plastic bottles for decorations.

4. I pollute the streams pouring or throwing waste..

3. I plant a tree every year in March ( not official-14th..

2. I pick up the rubbish wherever I come across.

1. I am an environmentally friendly citizen.

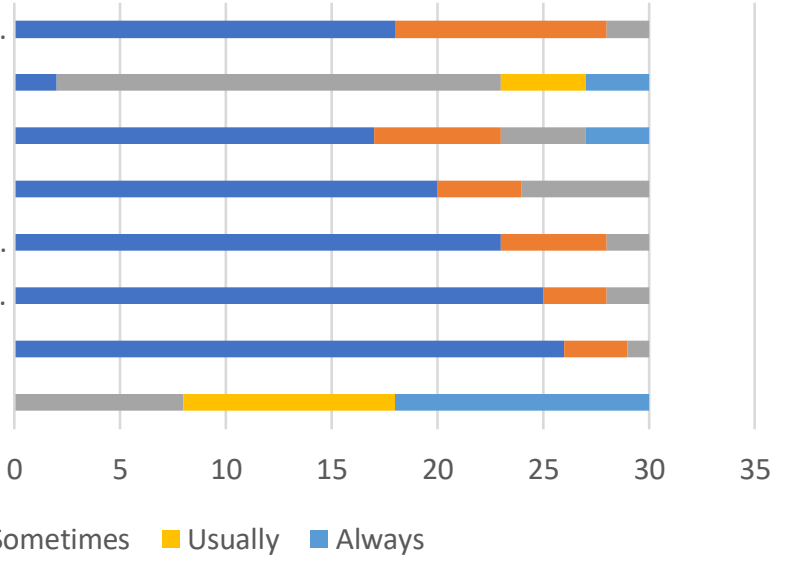

Figure 1: Students' response to 'What I understand from environmental awareness'

Based on the figure 1, it is clear that students do not pay attention on consuming water carefully and they do not care to clean the picnic area after they had the picnic and they do not use the plastic bottles for decorations.

However, they claim that they are environmentally friendly citizens.

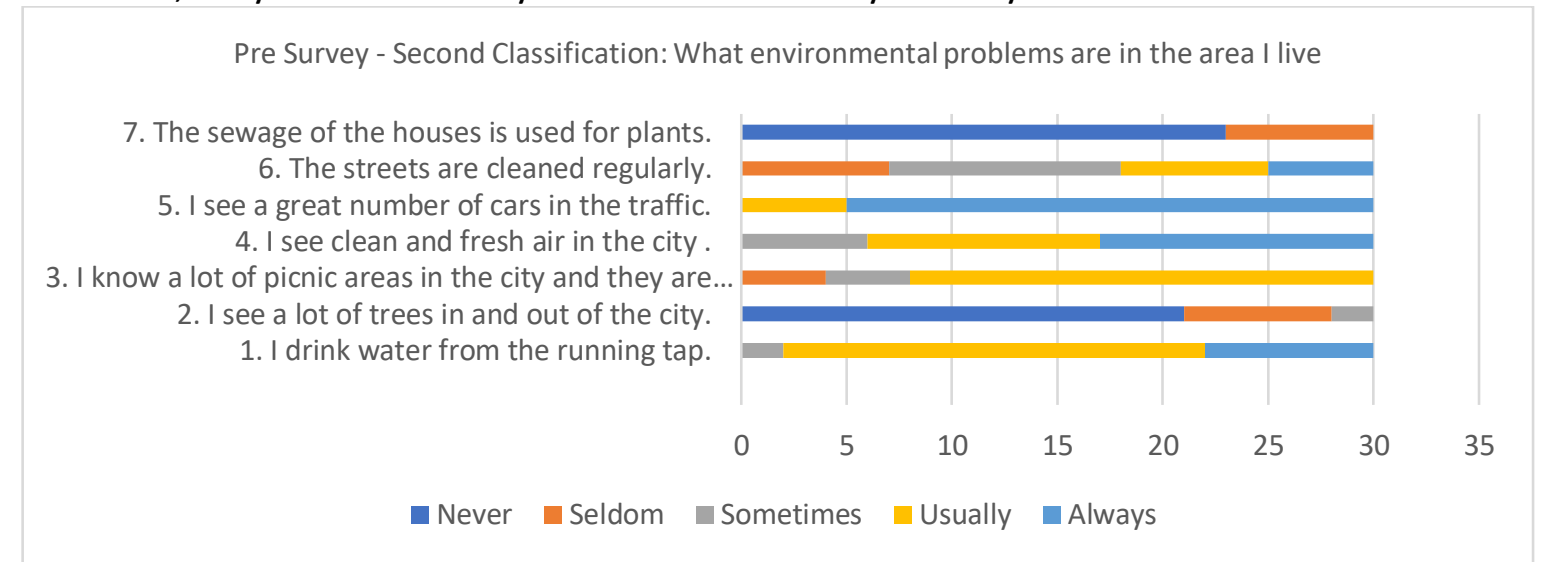

Figure 2: Students' response to 'What environmental problems are in the area I live'

Based on the figure 2, it is clear that students do not pay attention on drinking water from the tap, as it is a fact that public water is not clean enough, they think that picnic areas are clean enough but taken photos show that they are not, they believe that there are a lot of cars in the road and they cause air pollution and finally they do not think that the sewage from the houses are used for farming, but it is used. We can say that they partially know the environmental issues in their city. 
INTERNATIONAL JOURNAL OF ACADEMIC RESEARCH IN BUSINESS AND SOCIAL SCIENCES Vol. 9, No. 3, March, 2019, E-ISSN: 222 2-6990 ¿ 2019 HRMARS

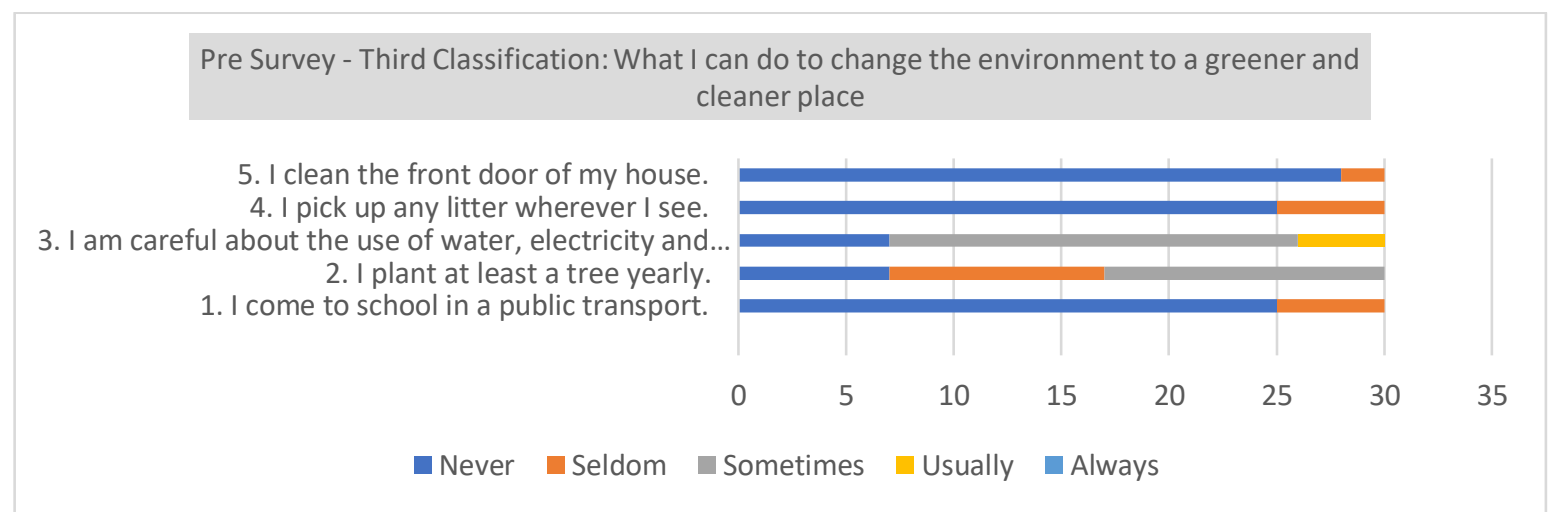

Figure 3: Students' response to 'What I can do to change the environment to a greener and cleaner place'

Based on the figure 3, students have the habit of coming to school in their own car, they do not intend to plant trees, they do not clean their own front door in their habitation.

\section{Students' Perceptions about Environmental Problems in the second Survey}

In 12 weeks education, students have gained the information from various texts from the textbooks and prepared presentations and posters as a way to improve their language skills. Teachers, peer groups and friends, curriculum, textbooks, posters on the school walls and activities are reported as the information sources. In addition to the formal curriculum, we strongly point out that the hidden aspect of the curriculum -the school walls, visual presentations, posters- promoted the students' awareness of environmental problems and issues. The posters on the walls were designed by the students. The messages given by these posters and pictures were not the same as those given in the books.

Post Survey-First Classification: What I understand from the environmental awareness

8. I throw plastic water bottles or fruit peels from the...

7. I clean the picnic area after having a picnic.

6 . I care closing the water tap if I see that running.

5. I re-use the plastic bottles for decorations.

4. I pollute the streams pouring or throwing waste...

3. I plant a tree every year in March ( not official-14th...

2. I pick up the rubbish wherever I come across.

1. I am an environmentally friendly citizen.

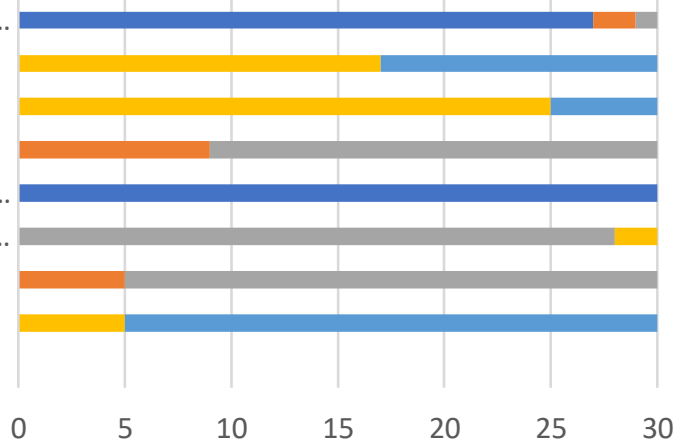

35

never Seldom $\square$ Sometimes Usually $\square$ Always

Figure 4: Students' response to 'What I understand from environmental awareness'

Based on the figure 4, it is clear that students' consuming water habit changed positively and they care to clean the picnic area after they had the picnic but they do not use the plastic bottles for decorations or different purposes in satisfactory mode and they are very sensitive about keeping the streams clean. 
INTERNATIONAL JOURNAL OF ACADEMIC RESEARCH IN BUSINESS AND SOCIAL SCIENCES

Vol. 9, No. 3, March, 2019, E-ISSN: 222 2-6990 ¿ 2019 HRMARS

However, they claim that they are environmentally friendly citizens.

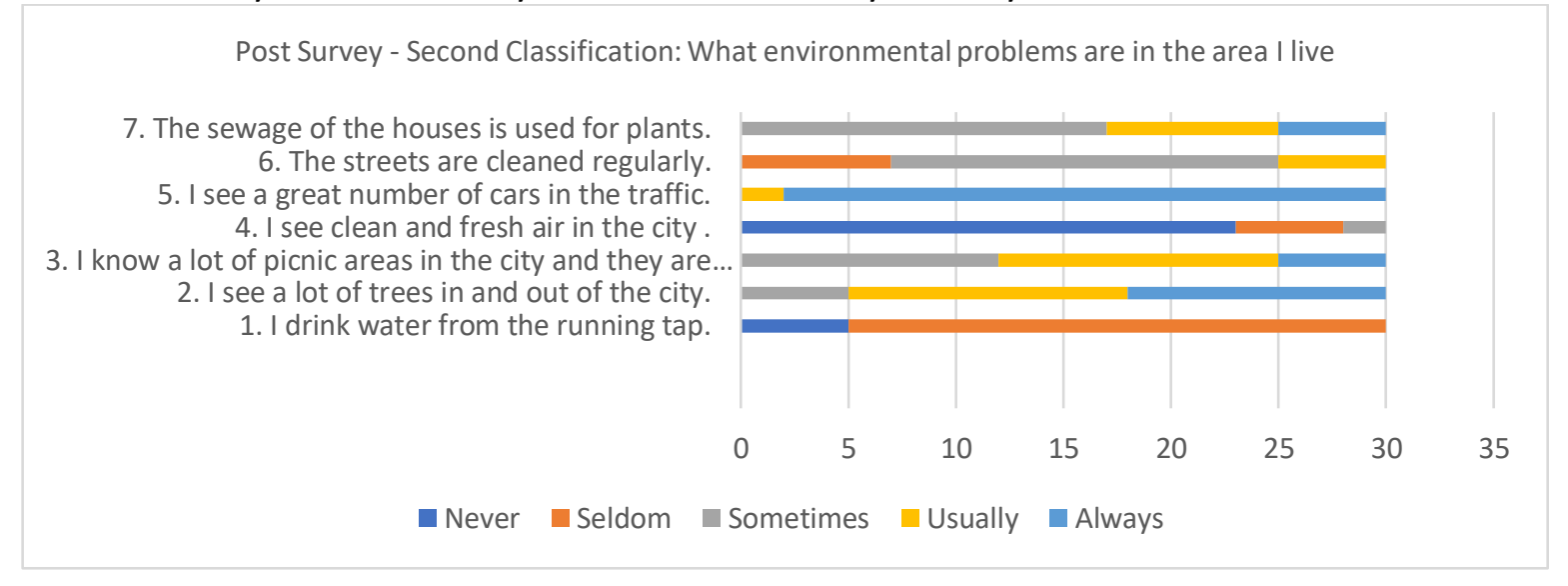

Figure 5: Students' response to 'What environmental problems are in the area I live' Based on the figure 5, they are more aware of not drinking from the tap, they are satisfied with the number of trees or green space in the city, but it is not enough, they do not think that the city is clean enough and this is right because in the mornings and evenings you may see the grey cumulative cloud on the city, the city has a lot of cars and surprisingly, students are sure that the sewage is used for farming.

Post Survey - Third Classification: What I can do to change the environment to a greener and cleaner place

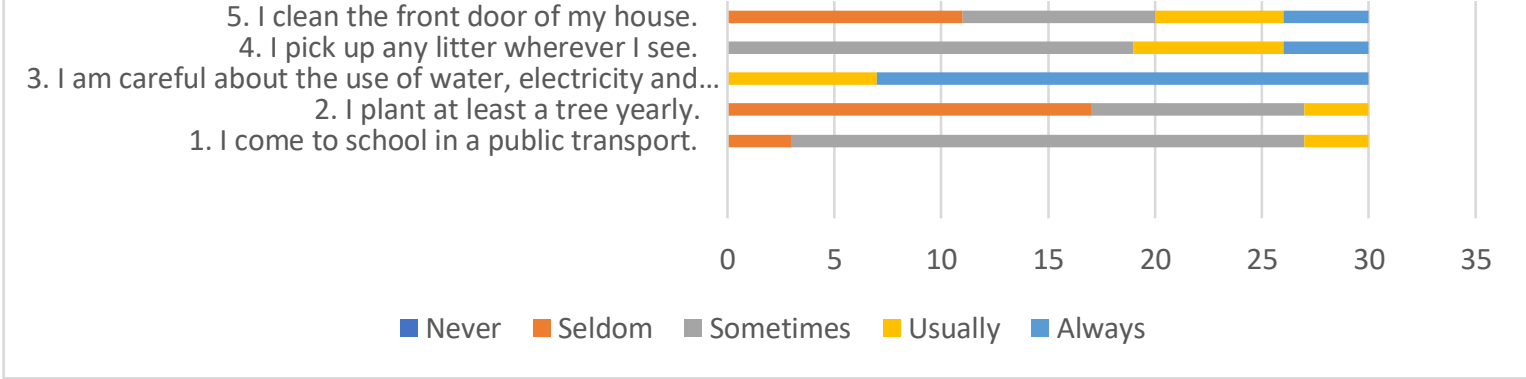

Figure 6: Students' response to 'What I can do to change the environment to a greener and cleaner place'

Based on the figure 6, there is a bit of positive change about their coming to school, they have some intentions to plant trees, they are more careful about the usage of paper, water and electricity, they are more aware of cleaning the environment.

\section{Conclusion and Recommendations}

Studying the figures regarding survey statements above, it is learnt that educators at schools should have curricular and extracurricular activities with learners to foster their awareness to environmental issues as it is seen that by different school activities, students' attitudes to nature and environment 
have changed positively slightly better. Although the researchers followed some activities with students are something beneficial and important, it had better to organize the learners in community projects more often could provide better results.

As this article being the combination of the researchers' observation, surveys and special interest about the role of extracurricular activities (Yildiz, 2016), they really appreciate to write and share the collected data regarding to improve the environmental awareness of students to the enthusiasts. Because, those ones whose environmental consciousness (Yerkes \& Haras, 1997) enhanced are considered to be knowledgeable about the environment and will demonstrate a high interest in and concern about responsible behavior to prevent environmental problems. Three main important elements, which are environmental knowledge, attitudes and behavior, and awareness can be transferred to learners with curricular or extracurricular activities. In the sphere of the school, teachers and the formal curriculum are the main source of environmental information for students. Thus, teachers, as the implementers of the curriculum have an important role in shaping students' environmental awareness, responsible behavior, and have a great responsibility to work harder than now to build environment friendly citizens. Moreover, news related to the environment on TV, the radio, in newspaper articles and on the internet can reach various students at all levels and increase students' level of awareness with regard to local and global environmental problems and issues. Books, family members and society are also considered as some of the sources of environmental information.

Living in Kurdistan, Iraq, with respect to ecological issues, learners can be benefited by studying the issues of worldwide natural issues in EFL textbooks. For example, public will be aware of corrosive downpour, an unnatural weather change, the consumption of the ozone layer, water deficiency, and problems emerging as a result of industrialization, urbanization, and rich but illiterate community. These issues can be conveyed in group work or individual assignment to search and students might be encouraged to give a talk in the class workshops.

\section{Acknowledgments}

I wish to thank various people for their contribution to this project; Dr. Bünyamin Çelik as the prep school director, Ms. Esra Ahmad as the admin assistant, Mr. Taylan Budur as the head of Business and Management Department in Sulaymaniyah Tishk International University, for their valuable technical support on this research; the foundation class students of interior and dentistry department students in Erbil, for their assistance in collecting the plant data as given honest replies in both surveys.

\section{References}

Brynjegard, S. (2001). School gardens: Raising environmental awareness in children. ERIC Document Reproduction Service No ED 452085.

Chawla, L., \& Cushing, D. F. (2007). Education for strategic environmental behavior, Environmental Education Research, 13:4, 437-452. 
Erdoğan, M. (2011). The Effects of Ecology-Based Summer Nature Education Program on Primary School Students' Environmental Knowledge, Environmental Affect and Responsible Environmental Behavior, Educational Science: Theory \& Practice, 11(4), 2233-2237.

Hattie, J., Marsh, H., Neill, J., \& Richards, G. (1997). Adventure Education and Outward Bound: Out of class experiences that make a lasting difference, Review of Educational Research, Vol. 67, No 1, 4387.

Howe, R.W., \& Disinger, J.F. (1988). Teaching environmental education using out of- school setting and mass media. (ED 320 759).

Hungerford, H., \& Volk, T. (1984). The challenges of K-12 environmental education. In A. Sacks (Ed.), Monographs in Environmental Education and Environmental Studies, Volume I, 3-30.

Kadji-Beltran, C., Barker, S., \& Raper, G. (2001). Primary School Pupils' Awareness of Environmental Issues: The Influences of Teaching Styles and Activities. Proceedings of the IOSTE Symposium in Southern Europe. Volume II, 400-411. ED 466370

Korhoren, K., \& Lappalainen, A. (2004). Examining the environmental awareness of children and adolescents in the Ranomafana region, Madagascar. Environmental Education Research, 10 (2), 195216.

O'Neal, L., \& Skelton J. (1994). A Field Trip to the Rocky Mountains to Teach Undergraduate Ecology. The American Biology Teacher Vol. 56, No. 4 (Apr., 1994), 233-237.

Palmberg, I.E., \& Kuru, J. (2000). Outdoor activities as a basis for environmental responsibility. Journal of Environmental Education, 31 (4), 32-37.

Palmer, J.A. (1998). Environmental education in the 21st century. London: Creative Print and Design. Smati, B. (2004). Environmental education in Tunisia. Sustainable Mediterranean (newsletter), 34, 78.

Ünal, S. \& Dımışkı, E. (1999). UNESCO-UNEP Himayesinde Çevre Eğitiminin Gelişimi ve Türkiye'de Ortaöğretim Çevre Eğitimi, H.Ü. Eğitim Fak. Dergisi 16-17, 142-154.

Wagner, E. (1997). Environmental attitudes in the elementary grades: A bibliographic essay. (ERIC Document Reproduction Service No ED 412 075).

Yerkes, R. \& Haras, K. (1997). Outdoor Education and Environmental Responsibility. (Report No. EDORC-97-6). Office of Educational Research and Improvement (ED), Washington, DC. (ERIC Document Reproduction Service No. RR93002012).

Yildiz, Y. (2016). The Role of Extracurricular Activities in the Academic Achievement of English as Foreign Language (EFL) Students in Iraqi Universities (A Case of Ishik University Preparatory School). Doctoral Dissertation, International Black Sea University, Education and Humanities.

Yildiz, Y. (2016). Impact of Language-Oriented Extracurricular Activities on Academic Achievement in Language Preparation Schools, Journal of Education in Black Sea Region Vol. 1, Issue 2, 161-171.

Yildiz, Y. \& Celik, B. (2017). Commitment to the Teaching Profession. International Journal of Social Sciences \& Educational Studies, Vol.4, No.2, 93-97. 